\title{
Buddhist Economics Meets Agritourism on the Thai Farm
}

By Wanna Prayukvong ${ }^{1}$, Nara Huttasin ${ }^{2}$ and Morris John Foster ${ }^{3}$

1. The Network of NGO - Business Partnerships for Sustainable Development, Bangkok,

2. Faculty of Management Science, Ubon Ratchathani University, Ubon Ratchathani Province, Thailand, and

3. Kingston Business School, Kingston University, London, UK

Finalised version appears in International Journal of Culture, Tourism \& Hospitality Research,9(2), 2015, 183-199

Contact E-mails: wannapr@hotmail.com

foster@kingston.ac.uk 


\title{
Buddhist Economics Meets Agritourism on the Thai Farm
}

\begin{abstract}
Buddhist Economics differs significantly from mainstream (neoclassical) Economics in its ontological underpinning. This means that assumptions about human nature are different: the core values of mainstream economics are self-interest and competition in the pursuit of maximum welfare or utility; while in Buddhist Economics, "self” includes oneself, society, and nature, which are all simultaneously interconnected. The core values of Buddhist Economics are compassion and collaboration through which well-being is achieved leading to higher wisdom (pañña). Because of this, the interconnectedness of activities and relationships, even those not initially obviously so linked, is crucial. The aim of the paper is to demonstrate that both leisure and sustainability objectives can be achieved via Buddhist Economics informed agritourism. The theoretical argument is illustrated by a pilot study of an agritourism, package tour to visit the properties of Thai farmers involved with a project known as 'running a one rai farm to gain a one hundred thousand baht return'. This will reveal agritourism as a significant market channel to promote sustainable agriculture.
\end{abstract}

Keywords: Buddhist Economics; Agritourism; Sustainable Agriculture; One Rai; Thailand 


\section{Introduction}

As a result of global competition, Thai farmers face difficulties, which include low commodity prices and low productivities (Richter, 2006). Low commodity prices tend to come from farmers' weak negotiating power in the free market, resulting in a high dependency both on middle men (through the market mechanism) and governments (through subsidy programs). Low productivities may derive from low skills and low soil quality, stimulating farmers to use chemicals (e.g. pesticides and fertilizers) in their production process. This kind of chemical usage can have impacts not only on production costs (e.g. because of rising chemical costs) but also on the environment (e.g. as a result of soil contamination). This kind of contamination can lead to negative effects on the ecological system, as evidenced (in part) by the reduction of forest areas in Thailand since the introduction of the First National Economic and Social Development Plan in 1961. This is of course an indirect effect: the other cause of Thailand's deforestation has been rampant, and largely unchecked, illegal logging. In addition, there is concern about the potential shortage of Thai farmers in forthcoming years as Thailand's population ages. (National Statistical Office Report, 2011). While the present generation of Thai farmers is getting older, there is a high probability that the number of Thai farmers will decrease in the medium-term future because the younger generation is showing a low level of interest in applying to study in the faculties/departments of agriculture in higher education each year ${ }^{1}$. These factors, amongst others, are potential constraints on the Thai agricultural system.

In particular many of the typical, small-scale, Thai farms of which there are many (comprising just a few rai, with one rai being less than half an acre) simply do not generate an adequate income stream to sustain a family at anything but the most basic subsistence level. To get a sense of the type of operation in question, these 'farms' are rather like what have long been known in Britain as 'smallholdings'. The question for such farms and their owners is simply what if anything can they do to make their livelihoods more secure, besides taking on unrelated, second jobs to earn supplementary income.

This central question is the topic we address in this paper. Two possible approaches to answering the farmer's dilemma are proposed, the first is potentially a stand-alone solution and the second is posited as an adjunct to the first. Further, if these potential solutions are seen to be fruitful at the local level, they will, in aggregate, help to strengthen the overall Thai agricultural system. The first part of the solution is more aggressive pursuit of the so-called "running a one rai farm to gain a one hundred thousand baht return" sustainable farming project, organized by the Bank for Agriculture and Agricultural Cooperatives (BAAC) ${ }^{2}$ and is compliant with the King's Sufficiency Economy philosophy. The second strand is a proposal for an agritourism scheme to operate in conjunction with the small farms seen to be at risk, enacted within the context of pursuit of the royal sponsored approach to sustainable, organic farming. Underlying this proposed linkage is a concept of Buddhist Economic thought and hence management.

The aims of this paper are:

- to outline the BAAC's project promoting a sustainable, organic farming approach, which helps give practical delivery of the King's Sufficiency Economy philosophy; and to begin to explore

\footnotetext{
${ }^{1}$ http://www.dek-d.com/admission/29634/, retrieved 1 October 2013.

2 BAAC was established by the Thai government with the primary aim to enhance social and economic wellbeing of Thai farmers through financial services for agricultural production and rural development projects.
} 
- the potential of agritourism in Thailand as a way of enhancing the economic payoffs of organic farmers in Thailand who are farming within the King's Sufficiency Economy philosophy; and

- the potential attractiveness of this specialised form of tourism to urban Thais.

The empirical evidence for the second and third objectives is drawn from a pilot case study of such agritourism in the province of Chaiyaphum located in the poorest region of Thailand. The rest of the paper is organised as follows. There are sections which outline the underlying concepts of Buddhist Economics and agritourism, followed by a brief methodology section. We then outline the practical starting point, or first step, to achieve sustainable agricultural development represented by the "running a one rai farm to gain a one hundred thousand baht return" project. We then report on the "food safety tour package" project, our case study of an embryonic agritourism activity. Finally, we synthesise the results of this pilot, organically located agritourism study in the conclusion and make some initial recommendations on facilitating actions for the future.

\section{Buddhist Economics as a pluralist economic context for Thai Agritourism}

As sketched in the Introduction, our argument as the paper unfolds will be that small farm owners in Thailand might usefully adopt a two step approach to solving their problems of income inadequacy. Step one is to seriously consider moving to a more organically based style of farming underpinned by the thinking of the so-called Sufficiency Economy approach espoused by the King of Thailand. That Sufficiency Economy approach has an underpinning ethos rooted in Buddhist Economic thinking, as we explain in more detail later. Hence it is necessary to outline the essential nature of Buddhist Economics which is set out synoptically in this section. Step two of our proposed approach is for farmers who have followed step one here before to consider offering a variety of agritourism experience on their now more organic farms. So, logically, the Buddhist Economic approach espoused becomes in turn a part of the underpinning structure for the trialled agritourism variety.

Buddhist Economics differs significantly from mainstream (neoclassical) Economics in its ontological underpinning. This means that assumptions about human nature are different: the core values of mainstream economics are self-interest and competition in the pursuit of maximum welfare or utility; while in Buddhist Economics, a notion first proposed by E. F. Schumacher (1966), "self” includes oneself, society, and nature, which are all simultaneously interconnected. The core values of Buddhist Economics are compassion and collaboration through which well-being is achieved leading to higher wisdom (pañña). Because of this, the interconnectedness of activities and relationships, even those not initially obviously so linked, is crucial.

In this new, pluralist form of economics the core ingredients of neo-classical economics are moulded together with the, one can argue, more ethically acceptable premises of Buddhist philosophy with its search for a 'right way of living', one key component of the Buddha's Noble Eightfold Path to enlightenment. Given this initial moral premise, economic activities are required (or expected) to serve social interests before personal interests, and not to harm the environment, as far as is practically feasible, whilst also giving rise to harmonious and peaceful ways of living. One key aspect of the path to understanding, progressive enlightenment and hopefully arriving at, or close to, the goal of a right way of living is the need 
for practice, advised Gyatso (1995). For a more detailed exposition of Buddhist Economics as a pluralist, heterodox form of economic thought. (see Payutto, 1995, Puntasen and Prayukvong, 2007, and Prayukvong, 2005).

Overall then, Buddhist Economics may be seen as an adaptation of, or enhancement of, neoclassical economics focusing on the addition to the mix of a moral code of behaviour and practice upon which all consideration of normal economic variables must rest. The notion of interconnectedness is critical to understanding how the 'standard' economic and ethical elements cohere in the new heterodox entity which is Buddhist Economics. At the risk of oversimplifying what is a dynamic and complex model, one could explain the Buddhist economic model to a sceptic as a multi-attribute economic model in which the attributes are non-commensurable in measurement terms. Hence, it can only be properly understood as a model with multi-dimensional and heterogeneous outputs, which include items such as happiness, community contribution and self-wisdom, as well as the usual measures of economic output. (Prayukvong and Foster, 2014).

\section{The concept of Agritourism}

Agritourism is recognized as a potential economic driver in the rural area where agriculture is the main economic activity. (see e.g. Ramsey and Schaumleffel, 2006, Telfer, 2000, Wilson et al, 2001, Wilson, et al, 2006). It helps farmers to increase income by diversifying farm and ranch operations as well as surrounding areas to be directly connected with tourism, thus bringing in visitors to the farm. This in turn increases cash flows through visitor expenditure on hospitality/food/beverage services (e.g. farm stays), on-farm direct sales (e.g. roadside stands and self-picking), and off-farm direct sales (e.g. farmers' markets, fairs, and special events) (Wilson, et al, 2006). Hence, agritourism can be considered an instrument for rural development with its contribution to positive economic impacts, providing economic opportunities to sustain financial security for the farming family, maintaining viability of the agricultural sector and local communities, and creating jobs for rural residents. However, although agritourism is perceived by governments and farmers as an option for agricultural diversification, which could be critical to the sustainability of agriculture, there is curiously a lack of formal definition of agritourism in the literature. As a result, 'agritourism' is often used interchangeably with 'farm-based-tourism' and 'rural tourism' (see also Phillip et al, 2010; Barbieri and Mshenga, 2008). For this study we settled on a definition based around the three key characteristics identified by Phillip et al, which we explain in the following three paragraphs before positing that derived definition.

Phillip et al (2010) provide a classifying typology for agritourism based around three key characteristics: namely, whether tourist activity is based on the working farm; the nature of contact between tourism and agricultural activity; and, the degree to which tourists experience authentic agricultural activity. Our definition of agritourism for this paper will be based on those three characteristics, which we first enumerate. According to Phillip et al (2010), the term "working farm" indicates a place where traditional agricultural activities are undertaken, such as rearing animals or milking cows on the farm, cultivating the soil for agricultural production, producing and harvesting crops, and so forth. It addresses the working farm in the sense that agriculture is a way of life, implying its significance in terms of its social and cultural aspects. Thus while the farming activities are going on, visitors take this opportunity to experience the 
uniqueness of the farm and the agrarian environment (Burton, 2004). When there is nonworking farm activity, agritourism is identified as a subset of rural tourism.

Next, following Phillip et al (2010), the nature of contact is categorized into three kinds, namely: direct contact, indirect contact, and passive contact. Direct contact describes the agricultural activities embedded in tourist experiences such as milking cows, feeding animals, and planting and/or harvesting crops, implying the authenticity of agriculture. Indirect contact describes a secondary connection to agricultural activity in the context of tourist experiences, for instance, visitors buying agricultural produce, perhaps in forms of meals or souvenirs made on the farm. Passive contact indicates the separated operation of agricultural activity and tourism and only farm space is commonly used, (e.g. lodging service in farmhouse).

A final key characteristic of agritourism is the authenticity of the tourist's agricultural experience (MacCannell, 1973). According to MacCannell, by following Goffman's structural division of social establishment, authenticity in tourism is described in terms of "front" and "back" regions; the front region is the place in which customers and service persons meet and the back region is the place which service persons use to relax from (and/or prepare for) serving customers. Based on this notion, tourists desiring to have an experience of agricultural authenticity, including sharing real farm life have to enter the "back" region, e.g. by helping with farm tasks. However, some tourists may consider entry to the "back" region intrusive. As an alternative, they can engage in a semi-authentic experience, called "staged authenticity" (MacCannell, 1973) where they inhabit a social space allowing them to see the inner agricultural operation without getting their hands dirty (e.g. farm tours). This is regarded as inhabiting the "front" region. Thus, the extent to which tourists have direct or indirect contact with "working farm" activities describes a continuum of agricultural authenticity. Following Phillip et al (2010), by giving attention to the role of agricultural activity, the contact nature of visitors with agricultural activity, and the continuum of agricultural authenticity, a definition of agritourism naturally emerges. Embracing these three elements, agritourism in our pilot case study was defined as 'the actions of private actors (farmers) at Sufficiency Economybased, working farms delivering enjoyment, hospitality services, and educational experiences for visitors, while helping generate supplementary income for those actors.' The pilot scheme seeks to link the health consciousness of urban, potential agritourists with the organic, self sufficiency of those pursuing the 'one rai' project, thereby offering new, economic opportunities to small-scale organic farmers.

There are a variety of agritourism activities illustrated in the agritourism literature (see also Clark, 1999; Gladstone and Morris, 2000; Sharpley and Sharpley, 1997; Burton, 2004). We summarise them as follow: outdoor recreation (e.g. horseback riding, fishing, camping/picnicking, wildlife/rural scenery viewing and photography, hunting, wagon rides, and off-road vehicles), educational experiences (e.g. farm/garden tour, wine tasting, cooking class, aqua-cultural/horticultural demonstration, historical agriculture exhibits, cattle drive, and help work in farm), direct agricultural sales (e.g. on-farm sales, roadside stand, agriculturerelated crafts/souvenirs, and self-pick operations), hospitality services (e.g. farm stay, youth exchange, guest ranch, and guided tour), off-the-farm sales (e.g. farmer's market and agriculture fair), and entertainment (e.g. petting zoo, working animal training, and special events).

As mentioned above, the potential contributions of agritourism to regional development are enormous, seen in terms of a process to generate income for farmers, stabilize the local 
economy, reduce migration of young adults to big cities, improve social solidarity and local wisdom/pride, upgrade local facilities and services, and increase the sustainability of agriculture through an increased awareness of agricultural products in each region. However, in Thailand there has been relatively little attention to the development of agritourism from the perspective of regional development which could enhance the well-being of especially small farmers. Such agritourism as there has been to date in Thailand has tended to be been delivered by larger-scale farming enterprises, such as Chokchai Farm, Rai Plukrak, and Daily Home. These have tended to be something akin to agricultural theme-parks rather than the type of embedded experiential scheme outlined in the case study. For example, Chokchai farm has 'Thai cowboys' showcasing rodeo skills. Chemnasiri (2013) meanwhile has previously tried to assess the potential for agritourism in certain provinces in Thailand (Chonburi just east of Bangkok on the Gulf of Thailand and Phuket in the far south-west (although she used, as do some others, the word 'agrotourism' in lieu of agritourism). She suggests that there is indeed potential but that the rural communities where it would take place lack the organisation and marketing skills to make it happen. Her report appeared to be based on a more arms-length approach rather than the embedded model proposed later in this paper. Likewise Srikatanyoo and Campiranon (2010) claim that on the one hand Agritourism has begun to contribute to the growth of Thailand's tourism industry but that many Thai agritourism businesses are not successful as they do not understand what agritourists really want to experience. Their discussion is couched in terms of more show style activities rather than the deeply embedded approach defined above in terms of the typology of Phillip et al (2010).

\section{Methodology}

In order to gain insight into the potential of experiential agritourism, on organic farms, from the perspective of regional development in Thailand, exploratory research was conducted via a pilot case study. Given the exploratory nature of the research, in-depth, semi-structured interviews and direct observation were the methods used to collect data. [The very nature of the exploratory process indicates that there are no prior hypotheses under test and open-ended types of questions are best suited to the collection of the unhindered views of respondents, see for example Collis and Hussey (2003).] This data was collected over a two-day agritourism trip from Bangkok to Chaiyaphum located in the Issan or Northeast region of Thailand, during 22 - 23 June 2013, which served as an action research vehicle to identify the development of a sustainably innovative form of agritourism based on the Sufficiency Economic approach (see below for details).

The pilot study was wholly funded by the Network of NGO organisation, so participants paid no fee but at the end were asked what fee they felt they would be prepared to pay in the light of their experience. The study involved nine city-dweller, tourists, led by the primary organiser/researcher and her assistant, visiting four organic farms, located in Chaiyaphum province. These farms were conveniently grouped in a cluster not too far from the town of Khon Kaen, which is located some two hundred miles NE of Bangkok. This area is in the very heartland of the poorer, agricultural North East of Thailand (see the map in Figure 1).

$<$ Insert Figure 1, from end - here $>$

The farms were operated by graduates of the "running a one rai farm to gain a one hundred thousand baht return" project and in methods terms constituted a convenience sample, as 
indeed may be said of the complementary sample of 'tourists'. The researcher's activity was funded by the NGO organisation.

The trip program was arranged with the primary purpose of visiting the four selected farms, run by Mr. Chalermphon, Mrs. Thom, Mrs. Nuanchan, and Mr. Meuk, who operate Sufficiency Economy-based, organic farms in Chaiyaphum, . The subjects of the interviews etc were the four farmers and the nine trip participants ( 3 men, 6 women). The nine trip participants were professional people aged from 30 to 53. All are employed in the private sector and earn in excess of Baht30k per month, roughly $£ 600$ or $\$$ US950. The data collection was conducted by the two facilitators/researchers. The research assistant facilitated a focus group, collected observational data and transcribed interview recordings. He also acted as a confirmator (or otherwise) of the derived perceptions of the principal researcher.

As part of the trip program some leisure activities were included; for example, viewing scenery/waterfalls and watching hordes of bats at Phu Pha Man National Park, and shopping for hand-woven fabric/clothes at local community enterprises. To make the trip meaningful, all trip participants were required to make an overnight stay on one of the farms, arranged by the farmers and including the provision of indigenous food prepared from the farmers' organic produces.

\section{The "running a one rai farm to gain a one hundred thousand baht return" project}

In the context of Thailand, a discussion of sustainable development is mostly referred to in terms of His Majesty King Bhumibol's Sufficiency Economy project. Sufficiency Economy is a philosophy concerning the interrelatedness of three pillars: immunity (risk management), reasonableness, and moderation. Together with these pillars, there are two conditions that must be taken into account, namely knowledge and virtue. Since 1974 His Majesty the King bestowed upon the Thai population a New Theory of Agriculture as one of the concepts embedded in his Sufficiency Economy philosophy, because a majority of them were engaged in agricultural activities and a large number still are so employed, although the participation rate has gone down in recent times as Table 1 below shows. It should be noted that, whether he would see fit to use such a term or not, King Bhumibol's Sufficiency Economy project undoubtedly has, at its core, values which would allow us to describe it as being rooted in Buddhist Economic thinking. He is trying to encourage and to help the rural poor to be self sufficient, i.e. to be economically viable in their activities, and to do so in an ethical fashion rooted, as just explained, in ideas such as knowledge, virtue and moderation.

Increasing global pressures shaped the economic structure of Thailand, pressing it to transform from an agricultural to a more industrialized society. In addition, Thailand focused on shaping its economy to be at the forefront of economic development in East Asia, by emphasizing the importance of economic growth in terms of finance, tourism, and trade. In 1993, capital controls in the country were liberalised which resulted in an economic boom. The World Bank regarded Thailand as a leading player in the second wave of the "East Asian Miracle" (World Bank, 1993). However, because there was a speculative attack on the Thai baht by a number of international financial speculators, together with the real estate and stock exchange bubbles, the Thai economy slumped in 1997, followed by a period of economic instability through until 2001. Experiencing an economic decline, the Thai government adopted the SE philosophy to be the development direction of the country in 2002 as presented in the Ninth National 
Economic and Social Development Plan, up until now, the Eleventh Plan (2012 - 2017). The essence of the Sufficiency Economy philosophy generally requires persons/organizations to learn, rather than to be aware, in order to ensure that persons/organizations can attain selfreliance and generate immunity to cope with changes or impacts.

In the case of agriculture, at a practical level, the Ministry of Agriculture and Cooperatives and related government agencies have arranged training programs and/or trips for farmers to learn more about agricultural theory and to gain relevant skills in accordance with the Sufficiency Economy concept. However, most such training programs, which took place at customised, learning centres may be characterised as having used a 'demonstration approach', omitting the rich ingredient of 'learning by practising and doing'. To fill the gap, the Bank for Agriculture and Agricultural Cooperatives (BAAC) initiated the "running a one rai farm to gain a one hundred thousand baht return" project and cooperated with several organizations to promote sustainable development of Thai agriculture accordingly. These organizations included the Thai Chamber of Commerce, the Thai Chamber of Commerce University, and the Agricultural Land Reform Office. The Thai Chamber of Commerce formulated a training course, the Thai Chamber of Commerce University contributed 100 Rai (1 Rai $=0.4$ Acre) of university land to become a farming area, which the Agricultural Land Reform Office helped to transform into a learning and practice area. This land is located in Tambon Bangtanai, Pakkred, in the Province of Nonthaburi, just north of Bangkok. Project participants travel from all over Thailand to participate; they live and practice for five months to learn how to improve their agricultural productivity, in a sustainable fashion, leaving their own farms to the care of their families whilst they study.

Table 1 The economic structure of Thailand

\begin{tabular}{lcc}
\hline Sector & $\begin{array}{l}\text { GDP by Sector } \\
(\mathbf{\% )}\end{array}$ & $\begin{array}{l}\text { Labour force by } \\
\text { occupation (\%) }\end{array}$ \\
\hline Agriculture & 8.6 & 38.2 \\
\hline Manufacturing & 39.0 & 15.5 \\
\hline Wholesale and Retail Trade & 13.5 & 15.5 \\
\hline Construction and Mining & 4.3 & 6.1 \\
\hline $\begin{array}{l}\text { Transport, Storage and } \\
\text { Communication }\end{array}$ & 9.6 & 2.6 \\
\hline Other Services * & 37.9 & 23.4 \\
\hline$*$ Other services include the financial sector, education, hotels, and restaurants, etc. \\
\hline
\end{tabular}

Source: Bank of Thailand, 2011

(http://www.bot.or.th/English/EconomicConditions/Thai/genecon/Pages/

ThailandGlance.aspx)

The project provides an opportunity to eighty four farmers per cohort to participate in this fivemonth, action-learning based training programme; the participating farmers learn by selfdiscovery, informed by some formal lectures and training exercises, underpinned by the Sufficiency Economy approach, with its underlying Buddhist ethic. The training is run by a 
small pool of three, expert tutors, one of whom is the co-owner of the famous Tang Mo clothing brand. Each farmer is allocated a one rai plot on which to practice the theory. A roughly square plot has three elements: a central rice paddy area; then a water filled irrigation canal which can also serve to raise fish or shrimp; and an outer land rim on which participants are encouraged to grow vegetables. It is worth noting that action-based learning has rarely appeared in Thailand in an agricultural setting.

Through this action-based learning, BAAC conducted research to learn how to develop human capacity, raise Thai farmers' prestige, and explore the constraints/factors influencing farmers' learning capability. The research adopted an anthropological approach in which researchers recorded information about farmers' learning process of the agricultural training program, thus using an inductive approach, flexible data collection, and employing various instruments in the fieldwork. The main findings were:

1. The learning process in the agricultural action-based learning approach creates a "specialization" rather than "redoing" experience which results in increased productivity for the next agricultural production cycle. It is the specialization experience coming from problembased learning which helps to increase supplementary knowledge, develop skills, and raise awareness of the need for continuing education during the five-month, one production cycle training course.

2. The different rates at which agricultural yields and values were produced by each farmer were associated with multiple-factors such as the family status and the number of training events participated in the past five years. Agricultural yields and values produced reveal only part of the farmer's learning capability because low productivity might result from their experimental failure. As a result, this gives them a learning process of "learning from failure" that should or could give rise to improvement of agricultural productivity for the next production cycle.

3. One of the important outcomes of this training project (presented in a form of proper agricultural production management) is its contribution to a reduction of negative ecological impacts (including global warming) as well as an increased quantity of organic agricultural products. Not using chemicals results in an improved quality of soil in which valuable and useful bacteria and minerals are retained. Those retained bacteria and minerals are one of the indicators in measuring the fertility of soil, and thus sustainable agriculture.

4. After finishing the training project, 94 percent of the participating farmers are able to adopt and apply knowledge to their farms within less than 5 months. Besides, together with the support of BAAC in adjusting (e.g. digging) their farms, these farmers have co-operated with their neighbours to operate organic farms and to enrich the fertility of soil in both their farms and surrounding areas, benefiting not only the farmers and their families but also their community. This contributes to positive impacts towards the "here and there" social and ecological system, which is the ultimate goal of the project, aimed as it is at achieving sustainable development of agriculture through raising awareness of how to protect our ecological system which can be regarded as a public good at the global level.

Nevertheless, although the aforementioned outputs (the increased quantity of organic agricultural products and number of wiser farmers disseminating knowledge to other farmers) are considered successful, the distribution channel for organic agricultural products still heavily 
relies on the market mechanism (local market) which is the same distribution channel as nonorganic agricultural products. At the same time, there appears to be demand for organic agricultural products, but the forging of a closer link between urban customers, who have high purchasing power and organic producers living in the rural area seems difficult to bridge, primarily due to the transaction and transport costs determined by market mechanisms. To promote sustainable agriculture, there might be a mechanism other than government subsidisation which could help to develop the linkage between the production unit (farmers) and the distribution unit (markets). An horizontal form of network development, involving groups with an interest in solving the potential problem, could help to fill the gap. While there are no plans to roll out regional centres to replicate the programme, there is the possibility that graduates of the programme may be able to offer small scale training via training 'pods' annexed to their own land. One reason for there being no regional roll-out is the lack of specialist trainers with both the agricultural deliver organic knowledge and commitment to the underlying Buddhist thinking.

The presence in the project of the underlying Buddhist Economic thinking, which emphasizes collaboration and kindness as core values in driving the economy, offers hope for the horizontal development of the "running a one rai farm to gain a one hundred thousand baht return project" project, driven by past graduates. The same thinking suggests there to be potential for the experiential agritourism, which we now describe in the case study, as another form of horizontal development, or diversification in the language of strategy.

\section{The “food safety tour package" project}

The "food safety tour package" project was arranged as a pilot case study of agritourism based on Buddhist Economics thinking. It aimed to be a guiding prototype for an innovative and sustainable form of agritourism in Thailand. It was a specially organized trip that involved visitors in agricultural activities to gain educational experiences in the production processes of organic agricultural fresh food. Simultaneously, it provided an opportunity for visitors to morally support and encourage four farmers, who were selected from eighty-four farmers participating in the "running a one rai farm to gain a one hundred thousand baht return" project and who have succeeded in applying the SE philosophy's integrated agricultural knowledge to their daily life and farm operations. To some extent, the "food safety tour package" project tried to strengthen not only economic development by putting agritourism at the heart of development, with an expectation of market development for organic farm products, but also social development by reinforcing educational opportunities for both farmers (hosts) and visitors (guests). The farmers would learn how to welcome visitors hospitably and it was envisaged that the visitors would give moral support that could help the farmers keep their farms going. The visitors would gain valuable experience not only from consuming fresh organic products, but also from experiencing something different from their routine, urban lifestyle. This would perhaps provide visitors with new ideas for starting up businesses concerned with bridging the gap between other economic activities and agriculture in an innovative manner.

\section{Results}

A summative overview of the analytical results presents three main issues from the in-depth 
interviews and observation. These are encapsulated below from the supply side (selected farmers), the demand side (trip participants), and the trip management.

Supply side: Based on our in-depth interviews, the farmers greatly valued the support of the trip participants' visits, which helped to provide them with encouragement in their organic farm operations. They also felt that they could continue to benefit from such support in the future. Indeed, this support could be an inspiration deliver continuity of their organic farm operations.

"I am very glad and feel good to have people visit us. This implies their support. At least, I feel I am not walking alone. If it is possible I want visitors to come here again frequently. For the next group of visitors, I will prepare things as perfectly as I can and will show them how to grow the sugarcane." (Mr.Chalermphon)

"I am happy to know that people are thinking of us. This encourages us to keep our work going on...I also want everyone to come here again.” (Mrs. Nuanchan)

"We are so proud and feel encouragement given by customers because they make us realise that at least someone is concerned with what we have done...It is like we are not alone." (Mr. Meuk)

Behind their inspiration, the farmers showed their concern for the needs of visitors who had never experienced agricultural life by, for instance, dishing up a common, Thai main dish such as green curry, and providing a Thai farm, utility trailer (called Rot E-Tag) to transport visitors to the rice fields, which were at some little distance from the farmhouse. They thought that some visitors might not be able to handle the hot, spicy local food, so they prepared something with which urban visitors are familiar. Furthermore, they thought that travelling to the rice fields might cause visitors inconvenience because of the clay-sandy road which makes walking difficult. For this reason, Rot E-Tag were arranged to transport visitors for their rice field trips.

One of the farmers reflected on the possibility of pension arrangements for farmers through continuous income generation from, other than the existing organic rice/vegetable production, various kinds of fruit production, bearing in mind that Thai farmers have no access to a social security fund, whereby members of the fund can be reimbursed if they are sick, injured, unemployed, give birth, or die.

Demand side: All trip participants appreciated the way in which the farmers supply organic agricultural products for urban people. Some of them suggested that there should be an introduction, in the form of a video presentation, to the "running a one rai farm to gain a one hundred thousand baht return" project, as an orientation for their trip. It might also serve to enrich their knowledge regarding the practical adaptation of the SE philosophy to organic farming operations. Further, the trip participants valued the warm welcome and honest attitude of the farmers, as seen by: hospitality services concerning a cosy farm stay, a tasty meal prepared from organic farm products; the surprise of taking away local desserts and souvenirs (e.g. pillows and salted eggs), provided as a gift package for visitors to take home; and the transportation (Rot E-Tag) arranged for visitors to visit the rice fields. Based on our observation, the convincing evidence of the farmer hospitality services is that any time visitors finish their rice field trip or have a round-table discussion (usually on the patio) with farmers with regard to the self-reliant thoughts and acts in operating organic farms, the Issan indigenous desserts (e.g. bananas with sticky rice/Khao Tom Mat and Thai custard with sticky rice/Khao 
Neuw Sang Kha Ya) and local drinks (e.g. herb beverages) were supplied to visitors. This indicates a "care for others" reality, which is almost non-existent in the dynamic and competitive world system found in Thailand's big cities, and at the same time it provides us with an idea of the local, embedded culture of the Issan people. However, although the trip participants showed their enjoyment from participating in agricultural activities, they reflected their desire for authenticity of the farm phenomenon. The following are some of the trip participants' remarks from our interviews.

"I love all the local dishes here because of the beautiful taste and food safety but I don't want to have the central Thai, main dish [green curry] included because it is not the local food."

"I am so happy and excited to ride on a Rot E-Tag. It is my first time to ride on this kind of vehicle that makes me feel the agricultural authenticity."

"I like picking organic farm products and cooking very much."

"I prefer sleeping in a mosquito net because it is good weather here."

"The way the farmer operates his farm by using the Suriya Jukkawan [solar] system is so impressive."

Our observational findings revealed that the local food available included steamed glutinous rice, steamed Hom Nil or black jasmine rice, fresh/soft-boiled vegetables, steamed bamboo shoots with chilli paste, fried mackerel and giant water bugs with shrimp paste sauce, and spicy minced mushroom. It was observed that although most of the ingredients for food preparation were derived from the farmers' own farms and agricultural network, some ingredients had to be bought from outside. Ingredients from the farm and network included organic vegetables, mushrooms, catfish, eggs, and chicken, while those from outside the farms and network mostly comprised seasoning, grain, and mackerel.

In addition, since each farmer has different individual characteristic, it was not surprising that the trip participants were impressed by all of them. Nonetheless, it is interesting that these diverse characteristics are related to the socially oriented dimension, rather than the economically oriented dimension, such as: Chalermphon's willing sense of moral obligation to take care of his aged mother; Meuk's faithful and strong will to keep the organic farm operation going; Thom's creativity in applying his integrated knowledge to revive his fields; and Nuanchan's presentational skills of the application of integrated knowledge in the agricultural business. What's more, all trip participants expressed worries about the possibility of contamination of the visit farms because the surrounding areas comprised non-organic farms.

The nine tourists were asked at a debriefing session, during a travel break on the way back to Bangkok, what they would be prepared to pay for a similar trip experience in the future. Their responses were Baht 3k-5k; this compares with the actual cost of Baht 3k per head. Another piece of feedback was that the two day format with a very early start on day 1 and late arrival home on day 2 was slightly pressured. A three day-two night format with a gentler travel schedule was suggested, albeit the extra night would inevitably raise the price. But a Baht 5k price tag for a Thai mini-break is well within normal expectations. 
The trip management: Two of the main points to emerge for more efficient management from this familiarization trip are time management and tourist agricultural activities.

- Time management: Adverse or unusual weather conditions (e.g. unexpected rain and belated sunsets in the rainy season) caused and could again cause travel delays. For instance, the timetable of a journey may be planned to set off from Mor-Chit station (the northern Skytrain terminus in Bangkok) at 06.00 a.m. but because of heavy rain the departure time has to be delayed to 06.15 a.m.. A (rain induced) hour-and -a-half delay to dusk may lead to the suspension of watching a multitude of bats. Furthermore, the astonishing reality of efficient and effective farming operations - turning from an unproductive to a productive farm caused the trip participants' to really admire the lush vegetation on the farms. In addition, the trip participants noted their wish to talk or discuss with the farmers for longer than the scheduled time. All of which caused 'inefficiency' of time management, as can be seen from some of the following trip participants' requests for the next trip.

"It is more worth exchanging our knowledge related to growing organic veggies with the elderly than watching numerous bats...their network impressed me so much, so I think it would be better to reschedule our trip agenda."

"It will be nicer to arrive here in the evening time, so we can take a rest immediately and can get up very early to join picking backyard vegetables and cook by ourselves."

"The next trip should extend the visit program from 2 days/1 night to 3 days/2 nights or more than that because we want to learn more about the use of the integrated SE approach and experience the live farming lifestyle."

"If it is possible, we would like to learn practically and completely how to operate a one rai farm to gain one hundred thousand baht return and we don't want to stop by at other attractions, or such attractions should be categorised in an eco-tourism type."

"We spent too much time at Chalermphon's farm, if we had changed that to either Nuanchan's or Meuk's farm it would have been better."

- Tourist agricultural activities: The various agricultural activities with which trip participants had direct and indirect contact included: self-picking/cooking of organic vegetables; chatting with the local elderly to exchange ideas on growing vegetables and networking; admiring the green and impressive rice fields combined with the backyard gardens and the catfish pond; eating local food in the fields; spending time in the farm stay; riding on a Rot E-Tag to the rice fields; buying local products (e.g. hand-woven clothes); gaining new agricultural knowledge of the "marriage of the soil"; learning how the farmers apply the SE's integrated technology in their organic farm operations and routine-based activities; and experiencing the pattern of indigenous life (e.g. sitting and sleeping on the local sedge mats). In addition, the trip participants asked about the number of visitors for whom each farm could cater, particularly Chalermphon's farm and remarked that they wanted to embed themselves in the agricultural activities such as watering the vegetable farm in the early morning, picking whatever agricultural products on the farms one so wished, and allowing visitors to cook such produce according to their own desires or whims

Below are some of the reported views of the trip participants: 
"I want to spend my night in Nuanchan's farm, sleeping in a large gazebo with a mosquito net, waking up early for a very fresh air, watering veggies, picking them and cooking them. These would make my life happy."

"I want to include the self-picking and cooking in our activities...It is somehow like "DIY"; that is, if you want to eat something you can pick any agricultural products from the farm and then cook by yourself in the open kitchen."

"Pay 100 baht, and then you can take a basket to the farm and pick organic agricultural fresh...it would be a nice activity."

Beyond that, it is noted that the trip participants indicated their desire for a local tour guide, a specific meeting place, and more time to immerse themselves in the world of a vast and lush field.

\section{Conclusion and recommendations}

This article presents an initial exploration into the possibility of creating a bridge between the agricultural and tourism sectors, by using agritourism as a means for regional development with Buddhist Economics as the underlying concept to achieve sustainable development of Thailand's agriculture. We explored issues and challenges of agritourism through a pilot case study of a food safety, tour package and would like to argue that agritourism development in Thailand requires thorough checks of the readiness of the supply side and the possible potential of the demand side. The two-day agritourism familiarization trip described above is a good example of the kind of 'integrated development', involving good deeds or the offering of kindness, which are reflective of the core values of the Buddhist Economics concept. The conferment of benefits on two dimensions was exemplified: food safety and hospitality services from the supply side and the moral and socio-economic support from the demand side. The farmers were anxious to ensure that their visitors (whether Buddhist or Muslim) could eat local (organic) food, have an enjoyable time on the farm, and be satisfied with the hospitality offered. The trip participants exhibited their support for the idea that the farmers are going in the right direction, by producing organic fresh food, and at the same time felt that there is huge, potential demand for organic agricultural products in their urban setting now and in the future.

The prior existence, initiated some forty years ago, of the King of Thailand's Sufficiency Economic program and its more recent, philosophically linked, BAAC training program for small scale farmers, aimed at developing their competence in sustainable agriculture (the "running a one rai farm to gain a one hundred thousand baht return" project), offered and continues to offer a context for the kind of agritourism being espoused and is a program much valued by those who negotiate it successfully. Even if they do not adopt a fully organic style of farming back on their own land, a greater sensitivity to sustainability issues at their local level and the notion of developing a richer crop mix, even on their small scale farms, is a hopeful sign for the future of local agriculture in Thailand.

The evolutionary pattern of activity which we have proposed in our foregoing arguments, as one possible solution to the Thai small farmer's problem of inadequate income from his little farm, may be summed up as shown below in Figure 2. 


\section{Figure 2 Model of emergence of 'embedded’ agritourism within organic farming}

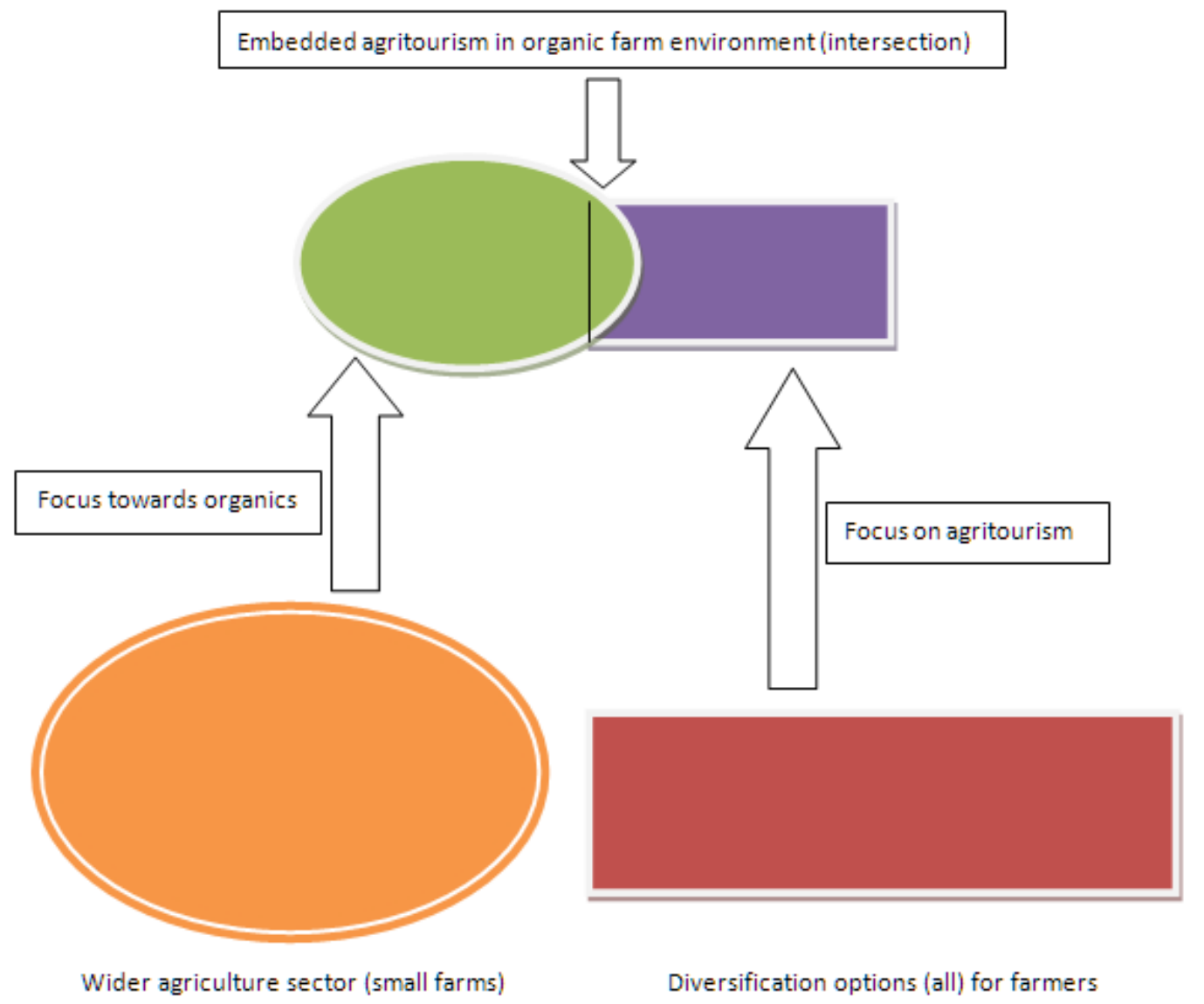

Sometimes the desire to show consideration, thinking of each other, created gaps between the supply side and the demand side, as evidenced by the undesired green curry. Although the hospitality of the farmers was impressive and was valued by the visitors, the agritourism product needs to be developed to better fit the tastes and preferences of both domestic and, in the longer term perhaps, international tourists. Conversely, the tourists need to be better prepared before the experience. They need to understand that they will be engaging in life as the farmers experience it, and to recognize that the point of the agritourism trip is to immerse themselves in a lifestyle that is different from their own.

Importantly, there is a need for a market-ready product development process, assisted by professional agencies, aimed at improving agritourism standards. This has an implication for the value-added context and content of agritourism, in which tourist agricultural activities should provide agritourism authenticity, or at least agritourism 'staged authenticity' experiences. Tourists from our postmodern society are willing to pay for authenticity of agritourism, essentially because such tourists are educational, and almost spiritual, experience seekers. To this extent, a wide variety of agritourism activities and lengths of time for visits remain challenges for agritourism development in Chaiyaphum and elsewhere.

One problem is that there is a lack of mediating actors who play a key role in matching both supply and demand sides. Thus, further research concerning the mediating actors who could encourage tourists to meet farmers is needed. Such research should support the development 
of Thailand's currently, small-scale agritourism business in the future. The pilot study reported here was funded by the NGO sector; if the scheme were to take off, seed corn finance would be required be it from government, the NGO sector or private firms who recognised the potential of this type of agritourism as a profit-making venture.

The style of agritourism, and the precursor "running a one rai farm to gain a one hundred thousand baht return" project, described in this paper has been described as being underpinned by Buddhist Economic principles. McGehee (2007) presents a possible systems model for agritourism development which embraces Weber's notions of formal and substantive rationality. By formal rationality he means that an economic actor should logically seek efficiency in their operation, while substantive rationality expects adherence to a particular conceptual or ideological system. These two types of rationality may underpin opposing aspects of economic life: they may conflict but have prudently to achieve an accommodation. As McGehee puts it (p.113): "often individuals have both formal and substantive reasons for engaging in economic enterprise." An obvious example would be the activities of the Quaker companies such as Cadburys and Rowntrees which in the early $20^{\text {th }}$ century sought to balance the profit drive of their businesses with the direct social welfare of their employees and their families and the wider communities within which they lived. Profit was not ruthlessly maximised because money was spent of the welfare element.

McGehee's model seeks to place each primary agritourism stakeholder group (agritourists, agritourism providers, and destination marketing organisations, DMOs) within the context of a formal and substantive rationality continuum, thereby engaging them in the most mutually beneficial relationships. There would seem to be parallels between this approach and our Buddhist Economic rooted model for agritourism development 'on the Thai farm'. The neoclassical aspect of the Buddhist Economic model takes the part of Weber's formal rationality and the adherence to the Buddhist philosophical aspect - the wider construing of 'self', the concern for the needs of others and the recognition of our richly interconnected natures - is evidently the substantive rationality of the Weberian view. Arguably the trickiest aspect of the whole thing is the setting of the relative weights, in the technical decision making sense, of the components, be it in the $\mathrm{BE}$ model or the Weberian conception. In all probability there will be no single right choice of weights but many right choices reflecting the philosophical stances of the actors present in the given setting. Finding where that point of balance may lie and indeed the very viability of a programme of organically based, immersive agritourism in Thailand will require, at a minimum, a more extended pilot project with several iterations. This could be undertaken by the original organisers, by the Thai government through some arm of its tourism operations or it could represent a speculative investment by an existing tour package operator. Alternatively it could be undertaken as a 'mixed' operation.

\section{References}

Barbieri, C., and Mshenga, P. M. (2008). The role of the firm and owner characteristics on the performance of agritourism farms. Sociologia Ruralis, 48, 166-183.

Burton, R.J.F. (2004). Seeing through the "good farmer's" eyes: towards developing an understanding of the social symbolic value of "productivist" behavior. Sociologia Ruralis, 14, 195-216. 
Chemnasir, N. (2013). Community Potential Development for Sustainable Agrotourism in Thailand. Developing Country Studies, 3(5), 22-26.

Clark, J. (1999). Marketing structures for farm tourism: beyond the individual providers of rural tourism. Journal of Sustainable Tourism, 7(1), 26-47.

Collis, J. and Hussey, R. (2003). Business Research: A practical guide for undergraduate and postgraduate students, $2^{\text {nd }}$ edition, Basingstoke: Palgrave Macmillan.

Gladstone, J. and Morris, A. (2000). Farm accommodation and agricultural heritage in Orkney. In F. Brown (ed.), Tourism in Peripheral areas: Case Studies (pp. 91-100). Clevedon: Multilingual Matters Limited.

Gyatso, Tenzin (His Holiness the $14^{\text {th }}$ Dalai Lama) (1995). Illuminating the Path to Enlightenment. Ithaca: Snow Lion Publns (also published in 2002 by TDL Publications, Long Beach, CA).

King, J.E. (2002). Some elements of a post-Keynsian labour economics, in: Dow, S.C. and Hillard, J. (eds.), Keynes, Uncertainty and the Global Economy, Beyond Keynes, Vol. 2, Cheltenham: Edward Elgar, 68-87.

McGehee, N.G. (2007). An Agritourism Systems Model: A Weberian Perspective. Journal of Sustainable Tourism, 15( 2), 11-124.

MacCannell, D. (1973). Staged authenticity: arrangement of social space in tourist setting. The American Journal of Sociology, 79, 589-603.

National Statistical Office Report (2011). Key Statistics of Thailand 2011. Retrieved 3 April, 2013, from http://web.nso.go.th/en/pub/oth/541312keystat.htm

Payutto, P.A. (1995). Buddhist Economics ( ${ }^{\text {rd }}$ ed., in Thai). Komol Keemthong Foundation: Bangkok.

Phillip, S., Hunter, C., and Blackstock, K. (2010). A typology for defining agritourism. Tourism Management, 31, 754-758.

Prayukvong, W. (2005). A Buddhist economic approach to the development of community enterprises: a case study from Southern Thailand. Cambridge Journal of Economics, 29, 11711185.

Prayukvong, W. and Foster, M.J. (2014) Buddhist Economics meets Corporate Social Responsibility. International Journal of Economics and Business Research, 8(2), 175-192.

Puntasen, A. and Prayukvong, W. (2007). A Theorization of Buddhist Economics that Goes beyond Schumacher's Middle Way, and Thailand's Revival of Sufficiency Economy', paper presented at the Sufficiency Economy and Global Transformation: Carving Out a Realistic Path Towards Economic Change, Bangkok, Thailand, 20-21 April 2007.

Ramsey, M. and Schaumleffel, N. (2006). Agritourism and rural economic development. Indiana Business Review, 81(3), 6-9. 
Richter, K (2006). Thailand's Growth Path, from Recovery to Prosperity. World Bank Research Working Paper 3912.

Schumacher, E. F. (1966). Buddhist Economics, in: Wint, G. (ed.), Asian Handbook. London: Anthony Blond.

Sharpley, R. and Sharpley, J. (1997). Rural Tourism: An Introduction. Thomson Business Press.

Srikatanyoo, N. and Campiranon, K. (2010). Agritourist needs and motivations: the Chiang Mai Case. Journal of Travel \& Tourism Marketing, 27(2), 166-178.

Starkey, R., and Welford, R. (eds.) (2001). The Earthscan Reader in Business and Sustainable Development London: Earthscan.

Telfer, D.J. (2000). Tastes of Niagara; Building Strategic Alliances Between Tourism and Agriculture. International Journal of Hospitality \& Tourism Administration, 1(1), 71-88.

Wilson , F., Fesenmaier, D., Fesenmaier, J. and Van Es, J. (2001). Factors for success in rural tourism development. Journal of Travel Research, 40, 132-138.

Wilson, J., Thilmany, D., and Sullins, M. (2006). Agritourism: a potential economic driver in the Rural West. Economic Development Report. Colorado State University and U.S. Department of Agriculture Cooperating, February 2006 - EDR 06 - 01.

World Bank (1993). The East Asian Miracle: Economic Growth and Public Policy. World Bank, Washington DC. 


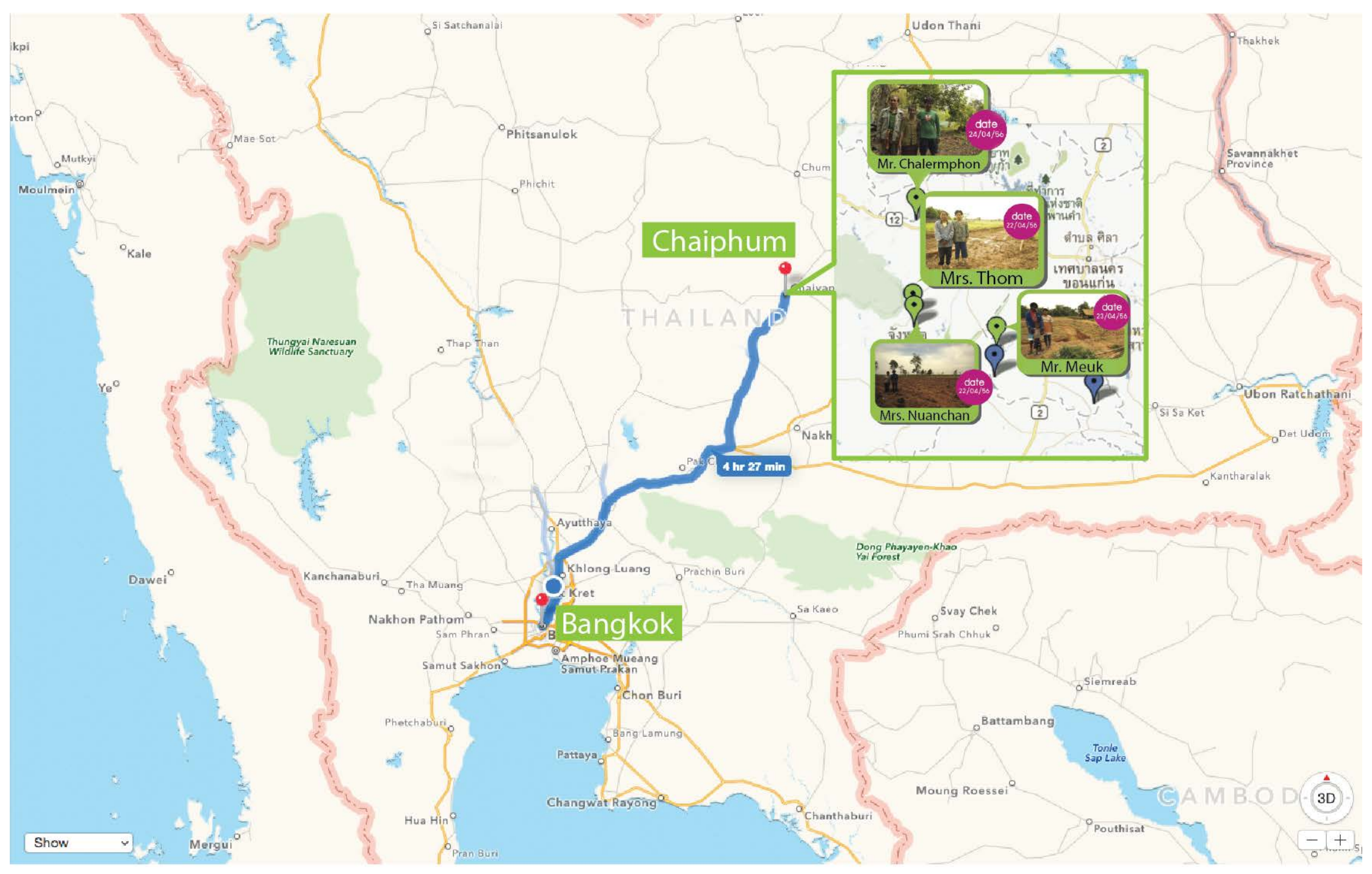

